\title{
Types of Personal Social Networks of Older Adults in Portugal
}

\section{Sónia Guadalupe \& Henrique Testa Vicente}

\section{Social Indicators Research}

An International and Interdisciplinary

Journal for Quality-of-Life Measurement

ISSN 0303-8300

Soc Indic Res

DOI 10.1007/s11205-019-02252-3 
Your article is protected by copyright and all rights are held exclusively by Springer Nature B.V.. This e-offprint is for personal use only and shall not be self-archived in electronic repositories. If you wish to self-archive your article, please use the accepted manuscript version for posting on your own website. You may further deposit the accepted manuscript version in any repository, provided it is only made publicly available $\mathbf{1 2}$ months after official publication or later and provided acknowledgement is given to the original source of publication and a link is inserted to the published article on Springer's website. The link must be accompanied by the following text: "The final publication is available at link.springer.com". 


\title{
Types of Personal Social Networks of Older Adults in Portugal
}

\author{
Sónia Guadalupe ${ }^{1}$ (i) $\cdot$ Henrique Testa Vicente $^{2}$ (i)
}

Accepted: 19 December 2019

(c) Springer Nature B.V. 2020

\begin{abstract}
This study presents and discusses a three-dimensional typology for personal social networks of Portuguese older adults. We used a K-means cluster analysis of structural, functional and relational-contextual variables of the networks of 612 participants aged $65+(M=76 \pm 7.6)$, mostly women $(63 \%)$. Four types of networks emerged: family networks, friendship networks, neighbourhood networks and institutional networks. The most frequent are family networks $(61.8 \%)$, constituted by $94.6 \%$ of family ties, on average, attesting the familistic nature of the older persons' networks in Portugal, followed by friendship networks (23.5\%) and neighbourhood networks (11.9\%). The less frequent type is the institutional network $(2.8 \%)$, dominated by formal ties $(M=59.3 \%)$. Sociographic profiles reveal that family networks are more likely to be held by middle-old focal subjects, married or widowed, and with children. Friendship and neighbourhood networks are held by young-old subjects with different marital status, many of them living alone, with a higher proportion of men with friendship networks. Institutional networks are held by old-old, widowed or single with no children. The presented typology contributes to understand social support needs and social isolation. The conclusions allow to anticipate social services' demand trajectories and to propose intervention plans and social policy measures to promote the wellbeing of the older population.
\end{abstract}

Keywords Social networks · Social support · Social isolation · Social ties · Older adults · Typology

Sónia Guadalupe

soniaguadalupe@gmail.com; guadalupe@ismt.pt

https://www.ismt.pt

Henrique Testa Vicente

henrique.t.vicente@gmail.com

1 Instituto Superior Miguel Torga/Miguel Torga Institute of Higher Education (ISMT), Centre for Health Studies and Research of the University of Coimbra (CEISUC), Largo Cruz de Celas, 1, 3000-132 Coimbra, Portugal

2 Miguel Torga Institute of Higher Education (ISMT), Research Centre for the Study of Population, Economy and Society (CEPESE), Coimbra, Portugal 


\section{Introduction}

Personal social networks can be considered the interpersonal niche of an individual, contributing to his sense of identity, and providing multiple types of social support, including emotional, instrumental and financial support, counselling and social regulation, among others (Guadalupe 2016; Sluzki 1996). Although social networks might entail conflict and deleterious effects in certain situations, they are frequently associated with various personal benefits, life satisfaction, well-being and health outcomes, which undoubtedly helps to explain researchers interest in studying them in old age (Litwin 1995a).

Studies that focus social networks in old age tend to identify certain common features that distinguish them from other age groups. Findings reported in the literature show smaller networks, mostly composed of long-term ties, usually kin relations, and less social participation. Available network ties seem to be supportive, but reciprocity tends to decrease with age (Litwin 1995a). Sluzki (1996) argues that the evolution of social networks in the final stages of the life cycle is characterized by a contraction movement due to a decrease in available network ties (also referred by Litwin 1995a, as "natural attrition"), less opportunities and diminishing motivation to renew the network, and more burdensome maintenance processes due to less energy and mobility.

However, these general tendencies should not obscure that diversity also exists in the social networks of old people (Guadalupe et al. 2019), and one of the methodological alternatives to address this heterogeneity has been to develop typological analysis. As Litwin (1995a) argues, identification and classification of different network types allows a better understanding of the patterns of diversity hidden behind average network measures. Besides allowing the recognition of the multiple interpersonal milieus in which older people function, Litwin and Shiovitz-Ezra (2006) observe that social network type is an important indicator of social capital and its measurement should concern all practitioners working with older persons. Network type is also considered a good predictor of social support (Cheng et al. 2009; Litwin and Landau 2000), autonomy/dependency (Doubova et al. 2010; Litwin 1998), health (Doubova et al. 2010; Li and Zhang 2015; Litwin 1998; Park et al. 2015), well-being (Cheng et al. 2009; Litwin and Shiovitz-Ezra 2011), involvement in social activities and community participation (Burholt and Dobbs 2014; Doubova et al. 2010; Li and Zhang 2015; Park et al. 2014), depression (Park et al. 2015), social risk (Litwin and Shiovitz-Ezra 2011) and isolation (Burholt and Dobbs 2014; Melkas and Jylhä 1996). Intimately associated with the multiple interactions with health and well-being variables referenced above, there exists a more or less generalized consensus in the literature that network typologies provide guidelines to social intervention planning, contribute to the promotion of better strategies and inform social service providers about emerging support needs, signal social vulnerabilities, anticipate life trajectories, and contribute to social policy debate (Burholt and Dobbs 2014; Guadalupe and Vicente 2019; Thiyagarajan et al. 2014).

Studies of social network type in old age date back to the 1980s and 1990s, to the ground-breaking work of several authors. Mugford and Kendig (1986) identified several types of networks among the elderly in Australia based on two variables (multiplexity of ties and network size). These ranged from "intense" (small and multiplex) to "diffuse" (large and uniplex) networks. Wenger (1991), through a research project in rural communities in North Wales that included both quantitative and qualitative methodologies, found five support network types: local family dependent; locally integrated, local selfcontained, wider-community focused and private restricted. This network typology had 
high predictive validity, allowing the identification of older people at risk, aiding the practitioner in the decision making process regarding interventions and also predicting mental health and hospital discharge outcomes, benefits take-up, likelihood of institutionalization and levels of carer stress (Wenger 1997). Litwin (1995a), with the aid of a unique and multifaceted network assessment inventory and a computerized classification system, found different network groupings in his study of Soviet elderly immigrants in Israel. Cluster analysis revealed four different types identified as kin, family intensive, friend-focused and diffuse tie networks, which mainly reflected variations in network composition. Also relevant was the finding that network assessment instruments were workable and produced a significant wealth of information, giving support to future endeavours at network inventory construction, with probe questions adapted to the aims of the investigator and to the population of interest.

The following decades saw a substantial increase in the number of studies and the proposal of several original network typologies. As it would be unpractical or even impossible to address them all, we resort to a recent cross-national literature review (Guadalupe and Vicente 2019) that identified some overarching tendencies: (1) network composition and size, frequency of contacts with network members, community participation and, particularly, the position of family ties are central variables to social network typology development; (2) many studies identify restricted and diverse types associated with specific social support features; (3) researchers frequently use multivariate K-means cluster analysis, an exploratory procedure that involves prescribing the number of clusters and trying several solutions; (4) there is an increasing recognition that typologies should be context grounded, that is, definition of network types must address ethnic and cultural specificities of the target population.

Typologies are based on a variety of network variables, such as type of ties and other morphological (size, density and composition) and transactional features (contacts, social participation, engagement), but the position of family ties emerges frequently as one of the key variables. Some typologies highlight family ties, specifying subsystems, conjugality or marital statuses in their definition (Burholt and Dobbs 2014; Doubova et al. 2010; Li and Zhang 2015; Litwin 1997b, 2001; Litwin and Shiovitz-Ezra 2011; Fiori et al. 2006; Fiori et al. 2007; Park et al. 2014, 2015). Family based network types appear with several designations, addressing different levels of relational intensity around family ties: family dependent (Wenger 1989, 1991); family intensive (Litwin 1995a; Melkas and Jylhä 1996); extended-family (Litwin 1997b; Stone and Rosenthal 1996); narrow family-focused (Litwin 1997b); family, familial or family focused (Cabral et al. 2013; Cheng et al. 2009; Fiori et al. 2006, 2007; Li and Zhang 2015; Litwin 2001; Litwin and Shiovitz-Ezra 2011; Park et al. 2015); non-family restricted or non-kin (Burholt and Dobbs 2014; Cabral et al. 2013; Doubova et al. 2010; Fiori et al. 2006); couple-focused (Park et al. 2014); married/ co-residence (Park et al. 2015). Friendship ties are also determinant in network typology construction (Cheng et al. 2009; Li and Zhang 2015; Litwin 1995a, b, 2001; Litwin and Shiovitz-Ezra 2011; Park et al. 2014), being a relational sphere associated with the diversification and widening of interpersonal relationships and exchanged resources.

Regarding composition and network size, two extreme types are recurrently included in network typologies: restricted and diverse (Cheng et al. 2009; Doubova et al. 2010; Li and Zhang 2015; Litwin 2001; Litwin and Shiovitz-Ezra 2011; Park et al. 2014, 2015). These two types are associated with different social support characteristics: diversified networks with the subjects engagement with an extensive quantity and variety of social ties, marriage and parenting, potentially offering greater and diversified support, higher social capital, frequency of contact, social activities, well-being and beneficial health 
outcomes; by opposition, restricted and defective networks are associated with lower levels of the aforementioned features, greater isolation and social risk (Fiori et al. 2006; Li and Zhang 2015; Litwin 1997b; Litwin and Shiovitz-Ezra 2011; Melkas and Jylhä 1996).

Despite their methodological diversity, some general trends can be identified in network typology studies. Cross-sectional studies with large samples predominate (e.g. Litwin 1995a, b; Mugford and Kendig 1986; Thiyagarajan et al. 2014), but longitudinal studies are also used to establish typologies (e.g. Li and Zhang 2015; Park et al. 2014; Wenger 1989, 1991). Additionally, from the 1990s onwards, K-means cluster analysis appears as the most frequently used statistical procedure. This computerized analysis implies that the researcher prescribes the number of clusters in advance, often trying different solutions in search for theoretical goodness-of-fit and the final models' capacity to address the specificities of the target population and to identify vulnerable groups (Guadalupe and Vicente 2019). Predominantly, typologies agglomerate four types of networks (Burholt and Dobbs 2014; Cabral et al. 2013; Li and Zhang 2015; Litwin 1995a, b; Park et al. 2014), but five (Cheng et al. 2009; Doubova et al. 2010; Fiori et al. 2006; Litwin 2001; Litwin and Shiovitz-Ezra 2011; Melkas and Jylhä 1996; Mugford and Kendig 1986; Wenger 1989, 1991) and six types (Stone and Rosenthal 1996; Litwin 1997b; Fiori et al. 2007; Park et al. 2015) are also common. Smaller typologies are less frequent, but nonetheless exist (e.g. Auslander 1996).

Finally, although some studies try to replicate pre-existing typologies in different national contexts (e.g. Thiyagarajan et al. 2014), the cross-national literature review highlighted the importance of constructing original typologies, sensible to ethnic specificities and cultural heterogeneity. Effectively, most typologies have been developed to address the "majority" in Western societies, but attention should be paid to nonWestern countries or people living in Western countries but belonging to minority cultural groups, that might require different typological proposals (e.g. Burholt and Dobbs 2014). Differences between Western world countries should also be focused in network typology studies, considering that significant diversity exists within this large group of nations (for example, it is customary to identify a more familistic vein in Mediterranean countries when compared to their northern European counterparts).

In Portugal, Cabral et al. (2013) presented a typology based on network size and composition, with a probe question/network generator that elicited relations of trust, people with whom the focal person shares important issues, concerns or daily problems. Despite the major contribution to social network literature in the Portuguese context, the authors recognize that trust networks are relatively constrained in nature, inducing the respondents to favour family members (spouses and children) over non-family persons. Other studies used more robust and flexible instruments to network delineation, such as the IARSP (Alarcão and Sousa 2007; Guadalupe 2016), a network assessment tool based on the theoretical proposals of Sluzki (1996), and very similar to the one used by Litwin (1995a). The IARSP has significantly influenced network studies developed in Portugal, with its flexible nature attested by the instruments applicability to a wide range of populations, including the elderly, but these studies tended to have relatively small convenience samples, that considerably limited generalization possibilities and restricted the application of more robust statistical analysis procedures, such as cluster analysis. Therefore, a gap still persists in the Portuguese context, namely in the development of network typology studies with large samples and a more versatile and multifaceted instrument of data collection. 


\section{Materials and Methods}

\subsection{Methods}

This is a Social Network Analysis study with a descriptive and cross-sectional design that measured several continuous and discrete variables included in the structural, functional and relational-contextual dimensions of personal social networks of the older population in Portugal. This study resorted to a multivariate $K$-means cluster analysis, through the inductive method, following the indications of previous studies using the same methodology (Burholt and Dobbs 2014; Doubova et al. 2010; Giannella and Fischer 2016; Li and Zhang 2015; Litwin 1995a, b; Litwin and Landau 2000; Melkas and Jylhä 1996; Stone and Rosenthal 1996).

The study uses a non-probabilistic sample of the older adult population (aged 65+) living in Portugal. All participants were volunteers and signed an informed consent, after being recruited through strategic informant and snowball sampling techniques, and selected using age criteria. The sampling plan included the following sequential stages: (1) identification of potential respondents who met the inclusion criteria (age criterion, capacity to autonomously respond to the protocol questions, absence of impairments that might render the application of the research protocol unfeasible); (2) provide information on the purpose of this research and its goals; (3) request collaboration and informed consent; (4) heteroadministration of the research protocol. Data collection took place in the centre region of Portugal.

\subsection{Instruments}

Participants were characterized using a sociodemographic questionnaire and a multidimensional inventory for ego-network analysis (the IARSP or Personal Social Network Assessment Inventory) (Alarcão and Sousa 2007; Guadalupe 2016). The IARSP uses a multidimensional network generator with a role relation, interaction, affective and exchange approach (Van der Poel 1993), and no limits to the number of members the respondent wishes to include (Molina 2001): "Name the people you are related to, that are meaningful to your life and/or provide support". After listing all network members, respondents were asked to provide information about their relationships with them (IARSP includes 13 such questions, 8 with Likert scales). In the present study, we analyse the structural, functional and relational-contextual dimensions of personal social networks, following a three-dimensional conceptualization (Guadalupe 2016). The structural dimension includes: (1) network size; (2) network composition by relational fields (family, friendship, neighbourhood, work/professional and institutional relations); (3) network distribution-the proportion of relational fields/network size; (4) density. The functional dimension includes: (1) perceived social support (emotional, material and instrumental, informative, social company, access to new contacts); (2) support reciprocity. The relational-contextual dimension includes: (1) durability of ties; (2) frequency of contacts; (3) geographic dispersion; (4) age and gender homogeneity/heterogeneity in the network.

\subsection{Participants}

Women constitute the majority of the sample (63.1\%). Participants are aged between 65 and 98 years $(\mathrm{M}=75.6, \mathrm{SD}=7.6)$; most are married $(52.2 \%)$ or widowed $(36.1 \%)$, do not 
live alone (78.8\%) and have children (88.2\%). Most had formal education (68.9\%), 51.3\% of which have four years of basic education. $92 \%$ are retired and $72.1 \%$ are not users of social services (Table 1).

\subsection{Statistical Analysis}

This study uses a multivariate K-means cluster analysis, through the inductive method, aiming at clustering groups with internal homogeneity and group heterogeneity. We then proceeded with one-way Analysis of Variance (ANOVA), after verifying the assumptions for the use of parametric statistics. The effect size was measured by Epsilon squared for ANOVA results. With four groups being compared, we used the Levene Test, and since the variance homogeneity was not assumed by all the variables under analysis, we opted

Table 1 Sociodemographic characteristics of participants

\begin{tabular}{|c|c|c|}
\hline & $\begin{array}{l}N=612 \\
n\end{array}$ & $\begin{array}{l}100 \% \\
\%\end{array}$ \\
\hline \multicolumn{3}{|l|}{ Sex } \\
\hline Male & 226 & 36.9 \\
\hline Female & 386 & 63.1 \\
\hline Age & $\begin{array}{c}(M=75.56 \\
D P=7.598)\end{array}$ & $\begin{array}{c}(\operatorname{Min}=65 \\
\operatorname{Max}=98)\end{array}$ \\
\hline “young old” [65-74] & 298 & 48.7 \\
\hline "old" or "middle-old" [75-84] & 223 & 36.4 \\
\hline "old-old" or "the oldest-old" [85+] & 91 & 14.9 \\
\hline \multicolumn{3}{|l|}{ Educational qualifications } \\
\hline Without schooling & 190 & 31.1 \\
\hline 4 school years & 314 & 51.3 \\
\hline 6 school years & 26 & 4.2 \\
\hline 9 school years & 32 & 5.2 \\
\hline 12 school years & 15 & 2.5 \\
\hline Higher education & 35 & 5.7 \\
\hline \multicolumn{3}{|l|}{ Civil status } \\
\hline Single & 44 & 7.2 \\
\hline Married & 321 & 52.5 \\
\hline Widowed & 221 & 36.1 \\
\hline Divorced & 26 & 4.2 \\
\hline \multicolumn{3}{|l|}{ Living alone } \\
\hline Lives alone & 130 & 21.2 \\
\hline Does not live alone & 482 & 78.8 \\
\hline \multicolumn{3}{|l|}{ Support of social services } \\
\hline No support & 441 & 72.1 \\
\hline With support & 115 & 18.8 \\
\hline Resident in home care & 56 & 9.2 \\
\hline \multicolumn{3}{|l|}{ Parenting } \\
\hline Doesn't have children & 72 & 11.8 \\
\hline Has children & 540 & 88.2 \\
\hline
\end{tabular}


for Games-Howell post hoc tests, suitable for groups of very different sizes, followed by $g$ of Hedges test for measuring the effect size. We also analysed the interaction between network types and sociodemographic and socio-familial variables through Chi square and Cramér's V tests contingency coefficients. All data analysis was conducted with the IBM SPSS Statistics 21 software for Windows.

\section{Results}

The social network multivariate analysis using the K-means clusters method included the entire data set, that is, all the aforementioned continuous and discrete variables of the structural, functional and relational-contextual dimensions served as discriminating criterion variables. After trying other solutions, a four cluster solution was adopted, considering not only the results of additional statistical analysis (differences between clusters in the criterion variables) and the number of cases in each cluster, but also the meaningfulness of the groupings, the models' capacity in addressing specific features of the Portuguese context and its goodness of fit with pre-existing theoretical or typological models.

Through centroid analysis of every personal social network characteristic included in the model, we verified some tendencies in each cluster, and found significant differences between groups in almost all variables, with the exception of two social support variables (informative and access to new contacts) (Table 2).

Labelling of network types was based on the major characteristic distinguishing network type/clusters: the variable network composition. Family dominates the first cluster, and although this relational field is also relevant in the remaining clusters, each of these has a distinct and diversified average composition of various network components (Fig. 1).

The first type of network, termed family network consists almost exclusively of family relationships, being restricted to kinship ties $(M=94.61 \%)$ and presenting a density level close to $100 \%$. It has the highest perceived levels of social support and reciprocity, and its members usually live in the same area and interact on a weekly or multi-weekly basis. It is the most frequent type of network in our sample.

In friendship networks, ties with friends stand out, assuming an average proportion almost at the level of family relations ( $M=42.59 \%$ vs. $48.03 \%$, respectively). Although friendship relations are not the most represented ones, their prominence leads us to consider that these networks are structured around a diversified set of social ties including both family members and friends (and a small portion of neighbours). Even though they are cohesive networks, their density levels are inferior to family networks. They include a larger number of relational fields, with high levels of emotional support but moderate levels of other types of support; they are also characterized by reciprocity, with its members living in the same area and with frequent contacts between them.

In neighbourhood networks, we find an investment in relations with neighbours at the same level as the one found with relatives ( $M=45.59 \%$ vs. $45.28 \%$, respectively), and a minor portion of friends. These networks have high density levels $(M=96.65 \%)$ and moderate levels in their functional characteristics. Network members live very close to each other and have frequent contacts.

Finally, the institutional network is dominated by secondary or formal ties (which represent, on average, $59.26 \%$ of the ties), and seems to be dictated/influenced by a specific interactional context and the existence of support provided by social services. It is also the type of network with the lowest proportion of family relationships 


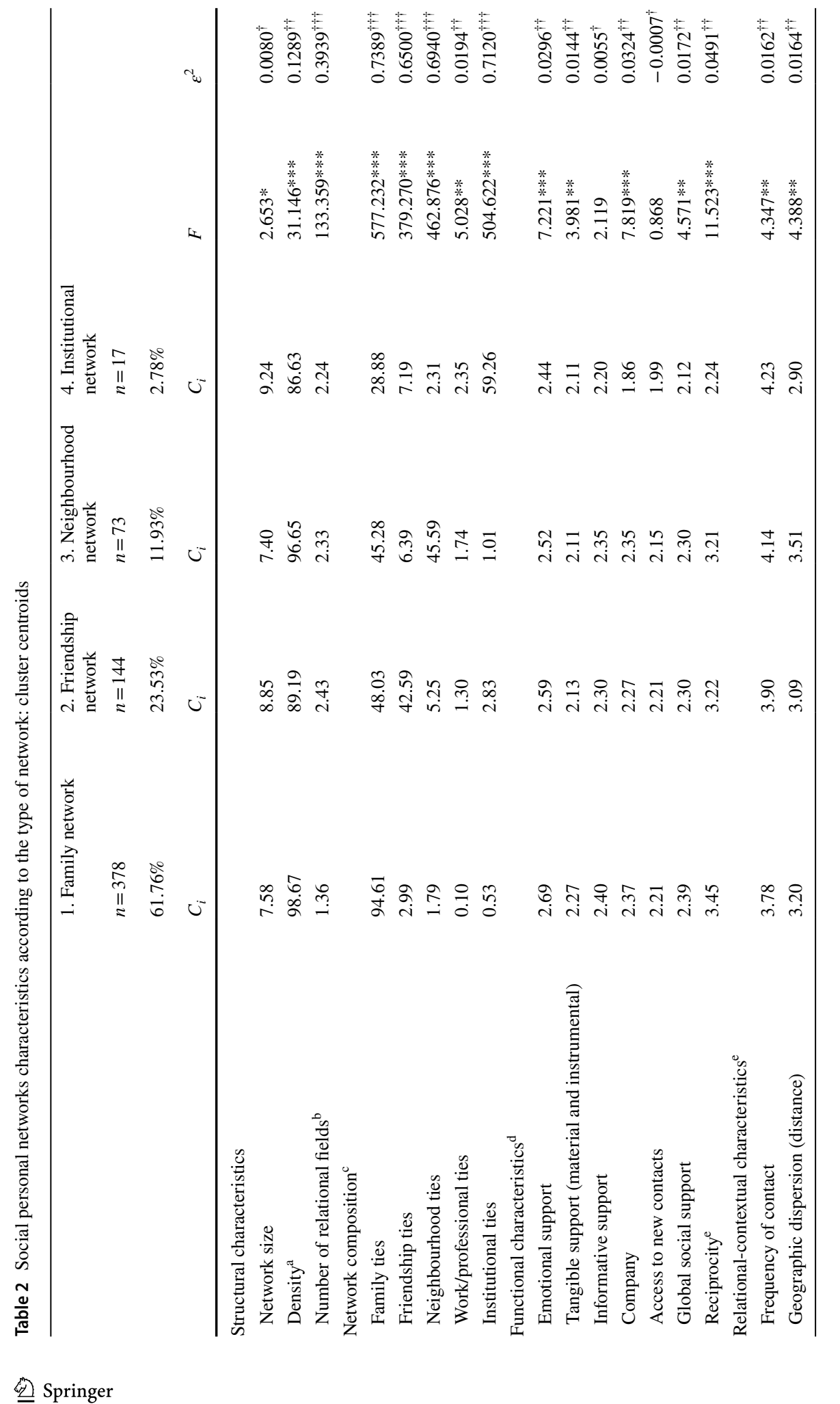




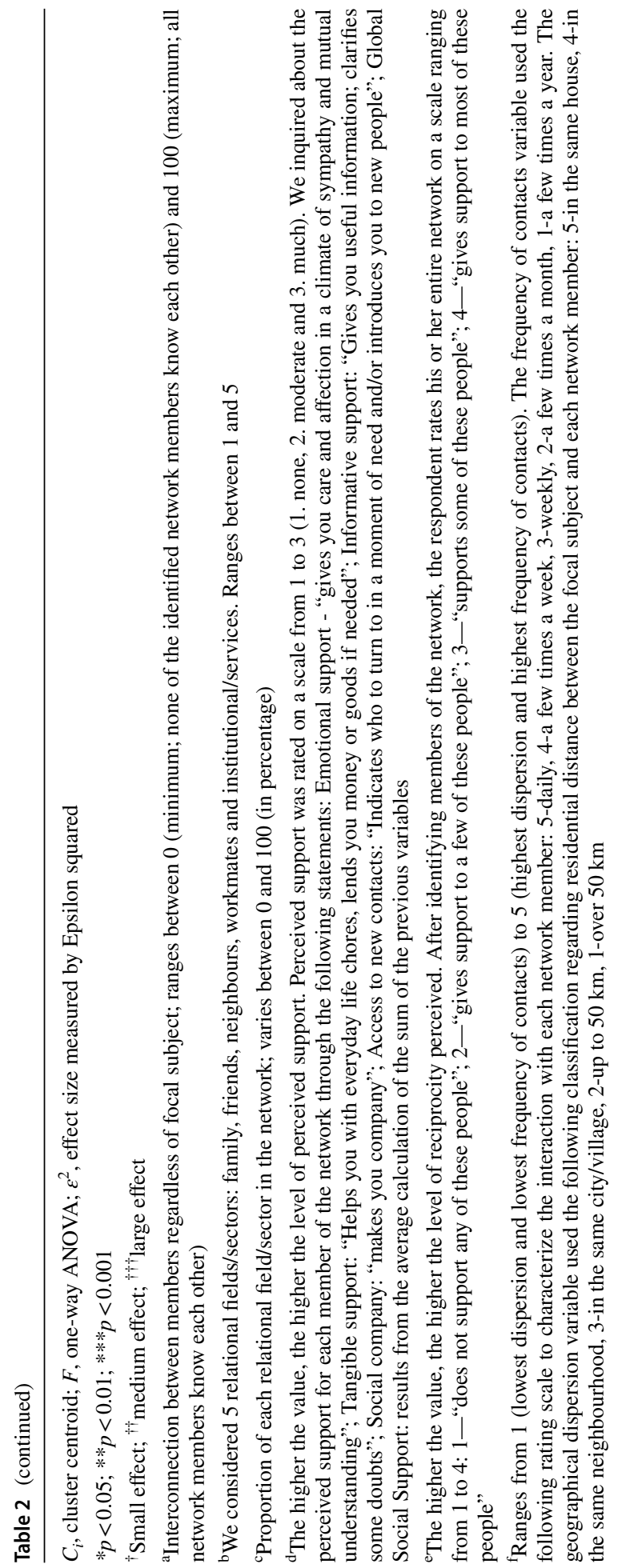




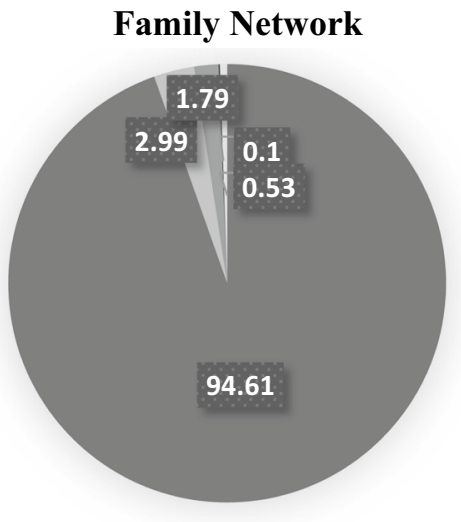

Neighbourhood Network

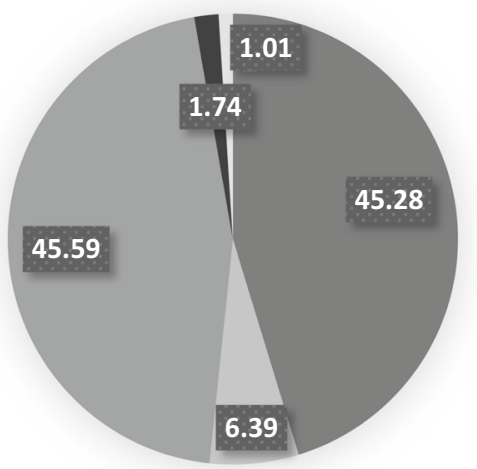

Friendship Network

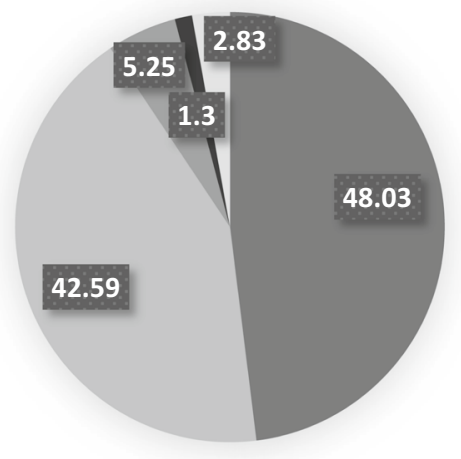

Institutional Network

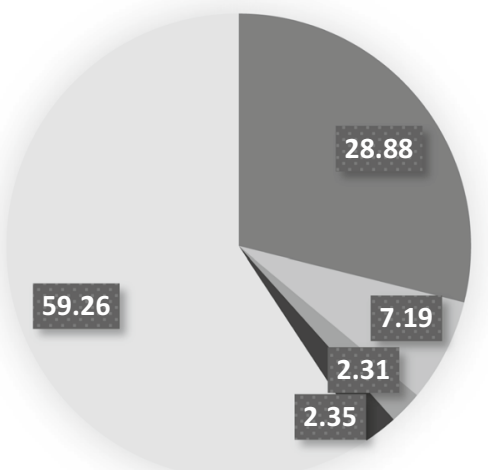

-Family ties $\backsim$ Friendship ties $\backsim$ Neighbourhood ties $\quad$-Working ties $\quad$ Institutional ties

Fig. 1 Composition of the four types of network found in Portuguese older population (values in percentage)

$(M=28.88 \%)$. This type of network presents moderate levels of support, interaction is frequent among its members (almost on a daily basis), and there is some geographical dispersion among them.

To further analyse the extent of the structural, functional and relational-contextual differences among network types, post hoc tests were carried out (Table 3). Despite the heterogeneity of clusters, some variables do not show differences between groups in the post hoc tests, such as network size, the proportion of work/professional ties, and support in the access to new contacts $(p>0.05)$ (Table 3$)$. Analysing the differences for each variable among network types, we observe that: besides the composition variables, family and friendship networks have different density, emotional and tangible support levels; also besides the proportion of network members in different relational fields, family and neighbourhood networks have distinct frequency of contacts and geographic distance; family and institutional differ significantly on various support measures, frequency of contacts and proximity; friendship and neighbourhood networks are distinguishable only by their composition distinctive features and their density levels; friendship and neighbourhood 
Table 3 Differences in personal social network characteristics between network types (Games-Howell multiple comparison test)

\begin{tabular}{|c|c|c|c|}
\hline Type of network & Friendship network & Neighbourhood network & Institutional network \\
\hline Family network & 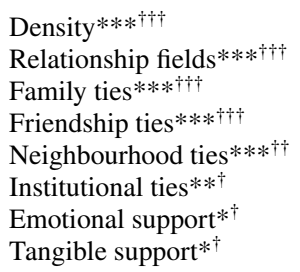 & $\begin{array}{l}\text { Relationship fields } * * *+\dagger \dagger \\
\text { Family ties } * * * *^{\dagger \dagger} \\
\text { Friendship ties } * \dagger \\
\text { Neighbourhood ties } * * *+\dagger \dagger \\
\text { Institutional ties } * * \dagger \\
\text { Emotional support } * *{ }^{\dagger} \\
\text { Frequency of contacts } * *{ }^{\dagger} \\
\text { Distance } * * \dagger\end{array}$ & 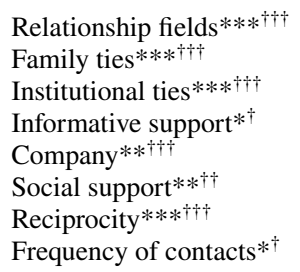 \\
\hline Friendship network & - & $\begin{array}{l}\text { Density } * * * \dagger \\
\text { Friendship ties } * * *+\dagger \dagger \\
\text { Neighbourhood ties } * * *+\dagger \dagger\end{array}$ & 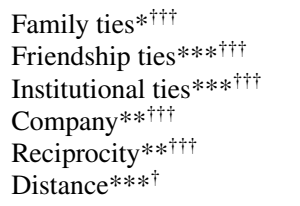 \\
\hline $\begin{array}{l}\text { Neighbourhood } \\
\text { network }\end{array}$ & - & - & 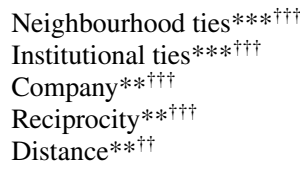 \\
\hline
\end{tabular}

$* p<0.05 ; * * p<0.01 ; * * * p<0.001$

${ }^{\dagger}$ Small effect; ${ }^{\dagger \dagger}$ medium effect; ${ }^{\dagger \dagger}$ large effect (Effect size measured by $g$ of Hedges)

networks differ from institutional networks in their composition, perceived levels of reciprocity and social company, and geographic proximity with network members.

The results show larger effect sizes in composition variables between groups. Functional/support variables, such as reciprocity and company, also present large effect sizes when comparing institutional networks with other types.

Network differentiation was also analysed through a cross-tabulation of sociodemographic variables with network type, allowing to add to the profile of reticular characteristics also a probable sociodemographic and sociofamilial profile for each network type (Table 4).

\section{Discussion}

\subsection{Designation of Network Types and Methodology}

This paper presents a typology of personal social networks of Portuguese older adults that integrates four network types, whose designations/labels make reference to the predominant relational field/sector in their composition: family network, friendship network, neighbourhood network and institutional network. Despite the familial/kin emphasis that permeates the first three types, the undisputed dominance of kinship ties clearly stands out in the family network, the most frequent in the study, representing almost $2 / 3$ of the cases. In this sense, even though family members prevail in most network types, the relevance of friendship and neighbourhood ties in two groupings justified labelling the second and third most 
frequent networks. Only the institutional network, the most residual in this study, with just $3 \%$ of the cases, has less than $1 / 3$ of family ties within it, being replaced with secondary or formal ties, that is, service providers and social service experts.

The definition of an institutional network type was one of the major results, as no such type appears in any of the reviewed typologies; and the persons with this profile are usually integrated in other types, such as: restricted networks (Burholt and Dobbs 2014; Cheng et al. 2009; Doubova et al. 2010; Li and Zhang 2015; Litwin 2001; Litwin and ShiovitzEzra 2011; Park et al. 2014; Wenger 1989, 1991), small and predominantly non-familiar networks (Cabral et al. 2013), or in the so-called defective networks (Melkas and Jylhä 1996). A relation with social services or institutionalization does not emerge clearly in the profiles associated with these types of networks in the aforementioned studies, but we find similar characteristics related to higher personal, relational and social vulnerability of subjects and networks.

The option for network type designations/labels based essentially on network composition, despite the integration of several structural, functional and contextual variables in the typological analysis, is also present in other typologies, both in relation to the general population (Giannella and Fischer 2016; Guèdon 1984; Vassilev et al. 2016; Wellman 1979) and to senior citizens (Burholt and Dobbs 2014; Cabral et al. 2013; Cheng et al. 2009; Li and Zhang 2015; Litwin 1995a, b, 1997a, 2001; Litwin and Shiovitz-Ezra 2011; Park et al. 2014). Some are focused on composition (Cheng et al. 2009; Li and Zhang 2015; Litwin 1995a, b, 1997a, 2001; Litwin and Shiovitz-Ezra 2011; Park et al. 2014) and the remaining have this network variable as an important reference.

As mentioned before, methodology followed the guidelines of other studies regarding inductive typology construction from data clustering (Burholt and Dobbs 2014; Doubova et al. 2010; Giannella and Fischer 2016; Li and Zhang 2015; Litwin 1995a, b; Litwin and Landau 2000; Melkas and Jylhä 1996; Stone and Rosenthal 1996). In the grouping process of network types, it is customary to include structural and functional network characteristics, but the way these variables are evaluated differs significantly between the reviewed studies, with these patterns of variation being mostly due to the nature of the instruments used to collect data. Most studies used questionnaires with closed-ended and scaled questions, self or hetero-administered through an interview. Other studies used social network assessment inventories designed specifically for that purpose, such as the inventory of Cochran et al. (1990), Litwin's (1995a) Network Assessment Inventory, or the sequential inventory, known as convoy model, by Antonucci and Akiyama (1987).

The reviewed studies do not always explain the network generator used, the probe question that establishes the boundaries for the inclusion of network members. However, the information derived from network studies depends greatly on the definition of social network adopted by the researcher and the method by which it is measured (Molina 2001; Tracy et al. 1990; Wellman 1996). Van der Poel (1993) systematizes four different approaches in network delineation: interaction, role relation, affective and exchange approaches. In the present study, we used an instrument that integrates several of these theoretical approaches: first respondents were asked to name those people most significant to them (affective approach); then they had to specify the type of relation with each network member (e.g. family or friend) (role relation approach); finally, respondents had to provide information regarding geographic distance and frequency of contacts with network members (interaction approach), as well as the supportive content of each relation identified (exchange approach). The assessment instrument used didn't place a limit to the number of network members (Molina 2001), but other studies had a predefined maximum number 


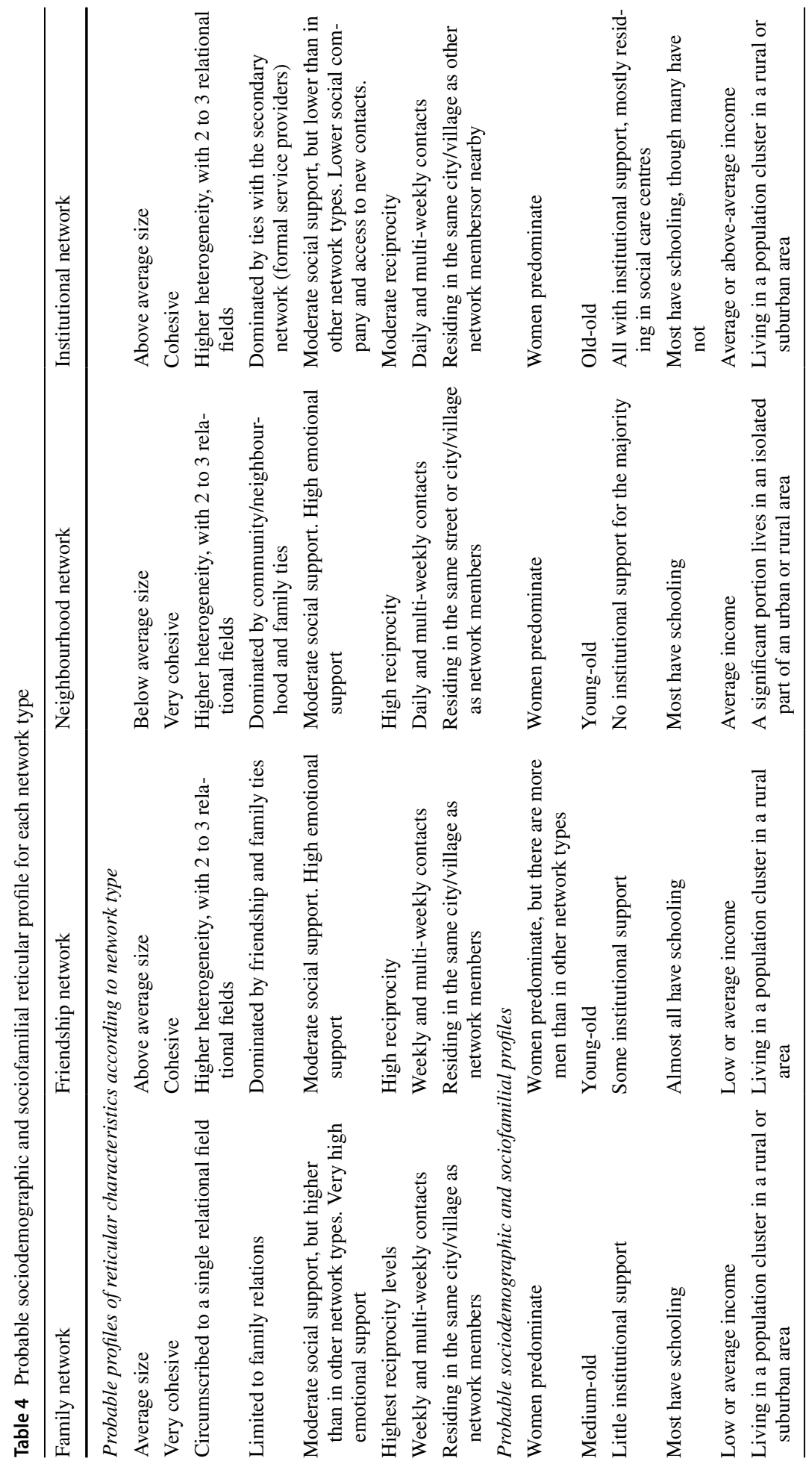




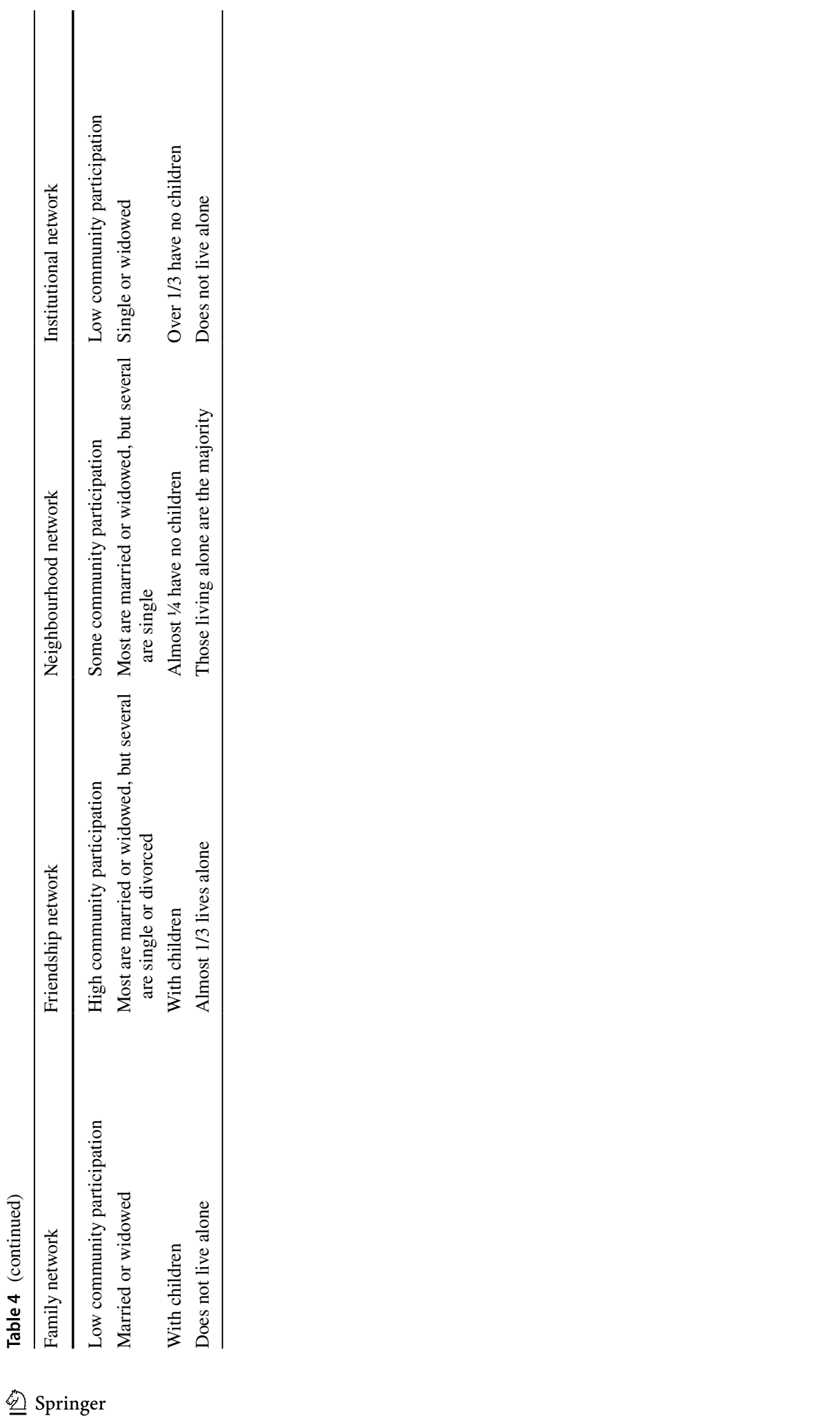


of eligible network members (Litwin 1995a, b; Cabral et al. 2013). These features allow to circumvent the restrictiveness of previous studies (e.g. Cabral et al. 2013) and to bring out a more nuanced and multifaceted picture of social networks in old age.

\subsection{Types of Network and Expected Profiles of Focal Subjects}

Social network typologization was the main goal and contribution of this work. Results of this classification of different network types present similitudes with several reviewed studies, despite differences in designations and cultural variations. We do not intend to go into a detailed discussion of cultural differences, but we should highlight a Portuguese cultural specificity as a south-western European country: the marked familism in relational networks and informal social provision.

The central role of families in social networks and informal support is well documented in Portugal (Aboim et al. 2013; Barbosa and Matos 2014; Cabral et al. 2013; Ferreira and Marques 2012; Fernandes 2001; Gil 1999; Portugal 2011, 2014; Vasconcelos 2005; Vicente and Sousa 2012) and in Southern European countries (e.g., Haynes et al. 2013). Thus, it was not surprising to witness this familistic dominance emerge in the social networks of Portuguese aged individuals, with $42.8 \%$ of networks exclusively composed of family ties and only $3.4 \%$ with no family members. Family constitutes the core of most networks (Guay 1984), particularly in later life (Lima 2010; Phillipson et al. 2001), and all reviewed typologies, without exception, mention network types composed of or dominated by family ties. Some typologies even highlight family subsystems, living conditions and conjugality or marital status, such as multigenerational households' networks (Burholt and Dobbs 2014), widowhood networks (Doubova et al. 2010) or conjugal networks (Park et al. 2014).

Although network size does not differ substantially among network types, family and neighbourhood networks are smaller and more cohesive than the rest. In the first case, confinement to a limited number of relations can be attributed to the limited heterogeneity of relational fields/sectors present in the network, which also occurs in family-dependent networks (Thiyagarajan et al. 2014; Wenger 1989, 1991; Wenger et al. 1996), family intensive networks (Litwin 1995a, b), restricted networks (Litwin 2001), encapsulated and affine networks (Portugal 2014), or minimal family networks (Vassilev et al. 2016). In the second case, networks are more heterogeneous but dominated by the relational possibilities offered by neighbour and family-related contexts, which might limit their amplitude depending on the number or availability of neighbours and the size of the family. The high levels of cohesion/density are related to the expected mutual recognition between neighbours and family members. This feature is positively associated with the networks capacity to recognize variations in the focal persons' support needs and with the ability to mobilize support quickly; however, high density levels are also associated with greater social regulation and centripetal functioning, facilitating conformity and promoting passivity, which may hinder the necessary changes when facing new circumstances and limit openness to new relationships (Guadalupe 2016; Sluzki 1996).

Residence proximity is also characteristic of these two types of networks. Other authors have already pointed out co-residence or residence proximity with children and other relatives as prominent in family-centred networks (Attias-Donfut and Renaut 1994; Cabral et al. 2013; Doubova et al. 2010; Ferreira and Marques 2012; Litwin 1995a, b, 2001; Melkas and Jylhä 1996; Park et al. 2014; Phillipson et al. 2001; Wenger 1989, 1991). By 
definition, low geographical dispersion and higher accessibility of significant others also applies to networks where neighbours assume centre stage.

Family and neighbourhood networks are also the most stable over time, with greater relational durability. Litwin (1995b) observed this situation in the more familial network types; Cabral et al. (2013) also identified longer relationships in predominantly familial networks, in contrast to more recent ones in predominantly non-familial networks, also pointing to a higher level of density in this type of networks. The same occurs in the present study. As for neighbours, greater durability of network ties is likely because $80 \%$ of the subjects in the sample lived all their lives in the same place or its immediate vicinity.

Neighbourhood ties appear in typologies associated to local or community-based networks (Doubova et al. 2010; Wenger 1989, 1991), friendship and neighbourhood support networks (Litwin 1997b). Some authors (Cheng et al. 2009; Doubova et al. 2010; Li and Zhang 2015; Litwin 1997b; Park et al. 2014; Vassilev et al. 2016) integrate this type of ties in diversified networks, although they are not always specifically mentioned as such in these studies. Only Litwin (2001) considers neighbourhood networks as an autonomous type of network.

The most diverse networks are friendship and neighbourhood networks, with higher relative frequency of contacts between focal subject and network members than family networks. This is a relevant indicator, given that such ties (specially friends) always present a certain inertia (Sluzki 1996), and when not activated/nurtured tend to deactivate and disconnect, a risk associated with the contraction of networks among older population (Fonseca 2011; Sluzki 1996, 2000). Although contacts within family networks are slightly less frequent, their relational lastingness (Portugal 2011) shows that a reduced interaction does not lead to loss of network members. Friendship ties or those with former co-workers usually require some sort of permanent reinforcement through their activation (e.g. meeting or talking) to prevent them from diluting to a status of non-significance.

Friendship and institutional networks are larger and less dense than the other types. However, the reasons behind these differences are probably different. Friendship networks are the most diverse, although essentially composed of friends and family. Friendship relations have the distinguishing feature of being built voluntarily and actively by social actors; as such, they are "particularly precious because they are unique" (Guay 1984, p. 51) and are influenced over time by the process of social-emotional selectivity (Carstensen et al. 1999). Despite the decline of contacts with friends in later life, as pointed out in a longitudinal study by Hatch and Bulcroft (1992), their maintenance depends on environmental, situational, individual and dyadic factors (Fehr 1996), in a complex conjugation favoured by reciprocity (Souza and Hutz 2008) and by opportunities for interaction (Peters and Kaiser 1985). Perhaps this is why it is usually associated with younger elderlies, with high social participation, mostly men, either single or divorcees, and living alone. Greater social participation and interaction with friends is highly dependent on functional capacity and availability, which is directly related to some of the subjects living alone or having no daily marital and/or family commitments.

These characteristics may also justify the lower relational durability when compared to neighbourhood and family networks, with greater openness to new relationships. Newer relations might carry with them a confrontation with different points of view, while older friendships have the benefit of a relational identity confirmation built from shared memories and greater intimacy, favouring confidence and counselling (Shea et al. 1988). Members of these type of networks live nearby, which seems to be relevant regarding social support within these relationships (Willmott 1987), providing support levels similar to those 
assigned to neighbours. Even if contacts are slightly less frequent than with neighbours, they are more frequent than with family members.

Although density levels are high, friendship and institutional networks are less cohesive than family and neighbourhood ones. This greater fragmentation, in the case of friendship networks, might favour the conciliation of different ties with different/concurrent demands. In a qualitative study with 60 +year-olds with active social participation, conclusions showed that they could manage and reconcile family and friendship relationships by separating them and dedicating time to each of these relational spheres (Araújo et al. 2012).

Other typologies also consider friendship networks (Cheng et al. 2009; Li and Zhang 2015; Litwin 2001; Litwin and Shiovitz-Ezra 2011; Park et al. 2014) or friend-focused networks (Litwin 1995a, b). However, the reviewed network typologies usually integrate friendship ties in networks with a broad or diversified composition, considered as extrafamily ties. That is the case of diverse networks (Vassilev et al. 2016; Litwin 1997b; Cheng et al. 2009; Li and Zhang 2015; Doubova et al. 2010; Park et al. 2014); open networks (Portugal 2014); restricted networks without relatives, extra-familiar or predominantly unfamiliar networks (Burholt and Dobbs 2014; Cabral et al. 2013; Doubova et al. 2010); career-friendship networks (Giannella and Fischer 2016); integrated networks of family and friends (Burholt and Dobbs 2014); and friendship and neighbourhood support networks (Litwin 1997b).

Institutional networks are the most residual in the present study, usually belonging to the oldest, widowed or single older adults, living in residential care centres or with frequent use of formal care services. As mentioned, none of the revised typologies includes a similar designation. However, in profiles associated with some types of networks, we find several characteristics associated with a greater personal, relational and social vulnerability of the subjects, although there is no clear reference to formal networks, such as restricted networks (Burholt and Dobbs 2014; Cheng et al. 2009; Doubova et al. 2010; Li and Zhang 2015; Litwin 2001; Litwin and Shiovitz-Ezra 2011; Park et al. 2014; Wenger 1989, 1991) or defective networks (Melkas and Jylhä 1996). The structural/functional patterns of these networks warrants further investigation. For example, in the study by Vassilev et al. (2016), results showed that subjects embedded in networks with weak ties have much more frequent contact with professionals. Although we need additional studies to clarify some of the particularities of this type of network, a relational vulnerability permeates the results. It is a large network, with various types of ties and low density levels, that favours the diversification of available resources. Nevertheless, considering the cultural context that favours family relations, the low percentage of family ties compared to other networks and the lower levels of perceived support and reciprocity, might result in less effective relational exchanges with formal ties, despite the guarantee of tangible support.

Studies have shown the importance of establishing friendships in the institutional context to promote well-being (Wolff 2013; Herrero and Gracia 2005), indicating more fragile support for older adults living in residential care centres (Herrero and Gracia 2005). In a study conducted in Spain with institutionalized older people, Zumalde (1994) found an average network size of 12.7 members, of which $45 \%$ are family members. The author found three distinct segments within these networks: an external network, with whom the subjects maintain a relation through visits (almost exclusively composed of relatives); a network composed of other residents, with several relational levels; and a network composed of the care centre staff, comprised of formal and technical caregivers (Zumalde 1994). Silva and Matos (2012), in a study comparing older persons users of three different types of social services, indicate that those residing 
in institutions present a smaller, less diversified and more family-centred network. Despite the decrease in affective contacts, family continues to be the most important social reference (Fericgla 1992; Neto and Corte-Real 2013; Silva and Matos 2012). They are indeed the second most common ties in our results, right after formal ties (Neto and Corte-Real 2013), challenging the prevalent idea that institutionalization is associated with broken family ties (Ferretti et al. 2014; Rodrigues 2000). However, this should not obscure the possibility that formal service providers enter the scene when some developmental or unexpected fragility in family ties or difficulties in ensuring support emerges. In a qualitative study by Rodrigues (2000), $46 \%$ of the residents in a care home in the northern region of Portugal had no children, and $33 \%$ had their children emigrated.

Functionally, family networks are associated with higher levels of perceived support and reciprocity. Individuals within this type of network rarely resort to social services; instead, they find a great variety of resources among family ties. Average support levels are higher than in other networks, for all the types of support evaluated. They are different from friendship networks regarding emotional and tangible support; from neighbourhood networks regarding emotional support; and from institutional networks concerning informative support, social company and social support in general. Hence, results indicate that family networks are more supportive than other types of network, though this might be due to the focal persons tendency to homogenise family members, granting them high support values (in some cases, resulting in an overestimation) and doing no kind of distinction between them (e.g. "if I said that my daughter gave me a lot of support, then I must say the same about my son"), which probably does not happen when ties are more diverse.

Litwin (1995a, b) has emphasized the multifunctionality and horizontality of family networks, stating that members of family intensive networks are the most prone to solidarity behaviours, and support reciprocity was shown to be higher in exclusively family networks, a view corroborated by Wenger (1991). Cabral et al. (2013) consider that greater emotional proximity and a greater level of support from predominantly family networks are influenced by physical proximity (that approaches its maximum in the case of spouses and sometimes children). Other authors also report that it is usually within family ties that effective responses concerning support in old age are found (Figueiredo 2007; Portugal 2011; Vicente and Sousa 2012), mainly by children (Attias-Donfut and Renaut 1994; Pardo et al. 2008).

\section{Conclusions}

Using a widely tested and developed methodology, this study presents a three-dimensional typology (including structural, functional and relational-contextual variables), with four types of personal social networks of the older population: family network, friendship network, neighbourhood network and institutional network. The first type is by far the most frequent, representing $62 \%$ of the cases, confirming the familial trend of Portuguese older people networks. The designations are based on the composition of the network since it was this structural variable that emerged as the major factor defining and distinguishing each type of network. The characteristics of each type are associated with sociographic profiles that confirm the literature on older adults' networks typologies. 
The type of network can be considered a strong predictive indicator of the need to resort to social services, as Wenger (1991) pointed out, taking into account the information it provides regarding availability of support and the transactional characteristics, and making it possible to anticipate trajectories and to propose preventive intervention plans. Type of network associated with the subjects profile regarding, for example, health, autonomy and participation characteristics, may support proposals for social policy measures, as well as suggestions for rethinking and redesigning existing social policies and for the creation of new social services focused on social relationships and wellbeing. Thus, this typology constitutes a contribution, both to the scientific community, and to the different professions working with the older population, highlighting the importance of personal social networks assessment, not only to guide intervention planning, but also to plan future researches.

Funding This research did not receive any specific grant from funding agencies in the public, commercial, or not-for-profit sectors. This research received the Prize Silva Leal by ISCTE-IUL and The National Secretariat of State for Social Security, Lisboa, Portugal.

\section{Compliance with Ethical Standards}

Conflict of interest The authors declared that they have no conflict of interest.

\section{References}

Aboim, S., Vasconcelos, P., \& Wall, K. (2013). Support, social networks and the family in Portugal: Two decades of research. International Review of Sociology, 23(1), 47-67. https://doi.org/10.1080/03906 701.2013 .771050 .

Alarcão, M., \& Sousa, L. (2007). Rede social pessoal: Do conceito à avaliação. Psychologica, 44, 353-376.

Antonucci, T. C., \& Akiyama, H. (1987). Social networks in adult life and a preliminary examination of the convoy model. Journal of Gerontology, 42(5), 519-527. https://doi.org/10.1093/geronj/42.5.519.

Araújo, C. K., Cardoso, C. M. C., Moreira, E. P., \& Wegner, E. (2012). Vínculos familiares e sociais nas relações dos idosos. Revista Jovens Pesquisadores, 1, 97-107.

Attias-Donfut, C., \& Renaut, S. (1994). Vieillir avec ses enfants. Générations et filiation, Communications, 59, 29-53. https://doi.org/10.3406/comm.

Auslander, G. (1996). The interpersonal milieu of elderly people in Jerusalem. In H. Litwin (Ed.), The social networks of older people: A cross-national analysis (pp. 77-97). London: Praeger.

Barbosa, F., \& Matos, A. D. (2014). Informal support in Portugal by individuals aged 50+. European Journal of Ageing, 11, 293-300. https://doi.org/10.1007/s10433-014-0321-0.

Burholt, V., \& Dobbs, C. (2014). A support network typology for application in older populations with a preponderance of multigenerational households. Ageing \& Society, 34, 1142-1169. https://doi. org/10.1017/S0144686X12001511.

Cabral, M. V., Ferreira, P. M., Silva, P. A., Jerónimo, P., \& Marques, T. (2013). Processos de envelhecimento em Portugal - Usos do tempo, redes sociais e condições de vida. Lisboa: Fundação Francisco Manuel dos Santos.

Carstensen, L. L., Isaacowitz, D. M., \& Charles, S. T. (1999). Taking time seriously a theory of socioemotional selectivity. American Psychologist, 54(3), 165-181.

Cheng, S.-T., Lee, C. K. L., Chan, A. C. M., Leung, E. M. F., \& Lee, J.-J. (2009). Social network types and subjective well-being in chinese older adults. Journal of Gerontology: Psychological Sciences, 64B(6), 713-722. https://doi.org/10.1093/geronb/gbp075.

Cochran, M., Larner, M., Riley, D., Gunnarsson, L., \& Henderson, C., Jr. (1990). Extending families: The social networks of parents and their children. Cambridge: Cambridge University Press.

Doubova, S. V., Pérez-Cuevas, R., Espinosa-Alarcón, P., \& Flores-Hernández, S. (2010). Social network types and functional dependency in older adults in Mexico. BMC Public Health, 10, 104. 
Fehr, B. (1996). Friendship processes. London: Sage.

Fericgla, J. M. (1992). Envejecer. Una antropología de la ancianidade. Barcelona: Anthropos.

Fernandes, A. A. (2001). Velhice, solidariedades familiares e política social: itinerário de pesquisa em torno do aumento da esperança de vida. Sociologia, Problemas e Práticas, 36, 39-52.

Ferreira, P., \& Marques, T. (2012). Redes sociais e envelhecimento. Actas do VII Congresso Português de Sociologia, Sociedade, Crise e Reconfigurações. Porto: APS.

Ferretti, F., Soccol, B. F., Albrecht, D. C., \& Ferraz, L. (2014). Viver a velhice em ambiente institucionalizado. studos Interdisciplinares sobre o Envelhecimento, 19(2), 423-437.

Figueiredo, D. (2007). Cuidados familiares ao idoso dependente. Lisboa: Climepsi.

Fiori, K. L., Antonucci, T. C., \& Cortina, K. S. (2006). Social network typologies and mental health among older adults. Journal of Gerontology, 61B(1), 25-32. https://doi.org/10.1093/geron b/61.1.P25.

Fiori, K. L., Smith, J., \& Antonucci, T. C. (2007). Social network types among older adults: a multidimensional approach. The Journals of Gerontology Series B: Psychological Sciences and Social Sciences, 62(6), 322-330. https://doi.org/10.1093/geronb/62.6.p322.

Fonseca, A. M. (2011). Reforma e reformados. Coimbra: Almedina.

Giannella, E., \& Fischer, C. S. (2016). An inductive typology of egocentric networks. Social Networks, 47, 15-23. https://doi.org/10.1016/j.socnet.2016.02.003.

Gil, A. P. M. (1999). Redes de Solidariedade Intergeracionais na Velhice. Cadernos de Política Social, $1,93-114$.

Guadalupe, S. (2016). Intervenção em rede: Serviço Social, sistémica e redes de suporte social (2nd ed.). Coimbra: Coimbra University Press. https://doi.org/10.14195/978-989-26-0866-2.

Guadalupe, S., Daniel, F., Testa-Vicente, H., \& Monteiro, R. (2019). Redes Sociais Pessoais e Trajetórias de Envelhecimento: Uma Perspetiva Etária e de Género. In H. Espírito-Santo \& F. Daniel (Eds.), Trajetos do Envelhecimento: Perspetivas teóricas e empíricas (pp. 395-424). Coimbra: Coimbra University Press. https://doi.org/10.14195/978-989-26-1737-4_10.

Guadalupe, S., \& Vicente, H. T. (2019). Social network typologies of older people: A cross-national literature review. Ciência \& Saúde Coletiva. http://www.cienciaesaudecoletiva.com.br/artigos/ social-network-typologies-of-older-people-a-crossnational-literature-review/17458? id=17458 \&id=17458. Accessed 23 Dec 2019.

Guay, J. (1984). L'intervenant professionnel face à l'aide naturelle. Montréal: Gaëtan Morin Éditeur.

Guèdon, M.-C. (1984). Les réseaux sociaux. In C. Brodeur \& R. Rousseau (Eds.), L'intervention de réseaux - une pratique nouvelle (pp. 15-33). Montréal: Éditions France-Amérique.

Hatch, L. R., \& Bulcroft, K. (1992). Contact with friends in later life: Disentangling the effects of gender and marital status. Journal of Marriage and Family, 54(1), 222-223. https://doi.org/10.2307/353289.

Haynes, P., Banks, L., \& Hill, M. (2013). Social networks amongst older people in OECD countries: A qualitative comparative analysis. Journal of International and Comparative Social Policy, 29(1), 15-27. https://doi.org/10.1080/21699763.2013.802988.

Herrero, J., \& Gracia, E. (2005). Redes sociales de apoyo y ajuste biopsicosocial en la vejez: un análisis comparativo en los contextos comunitario y residencial. Intervención Psicosocial, 14(1), 41-50.

Li, T., \& Zhang, Y. (2015). Social network types and the health of older adults: Exploring reciprocal associations. Social Science and Medicine, 30(130), 59-68. https://doi.org/10.1016/j.socscimed.2015.02.007.

Lima, M. P. (2010). Envelhecimento - Estado da arte. Coimbra: Imprensa da Universidade de Coimbra.

Litwin, H. (1995a). Unprooted in old age: Soviet Jews and their social networks in Israel. Westport, CT: Praeger.

Litwin, H. (1995b). The social networks of elderly immigrants: An analytic typology. Journal of Aging Studies, 9(2), 155-174. https://doi.org/10.1016/0890-4065(95)90009-8.

Litwin, H. (1997a). Support network type and health service utilization. Research on Aging, 19, 274-299. https://doi.org/10.1177/0164027597193002.

Litwin, H. (1997b). The network shifts of elderly immigrants: The case of Soviet Jews in Israel. Journal of CrossCultural Gerontology, 12, 45-60.

Litwin, H. (1998). Social network type and health status in a national sample of elderly Israelis. Social Science and Medicine, 46(4-5), 599-609. https://doi.org/10.1016/S0277-9536(97)00207-4.

Litwin, H. (2001). Social network type and morale in old age. The Gerontologist, 41(4), 516-524. https:// doi.org/10.1093/geront/41.4.516.

Litwin, H., \& Landau, R. (2000). Social network type and social support among the old-old. Journal of Aging Studies, 14(2), 213-228. https://doi.org/10.1016/S0890-4065(00)80012-2.

Litwin, H., \& Shiovitz-Ezra, S. (2006). The association between activity and wellbeing in later life: What really matters? Ageing \& Society, 26(2), 225-242. https://doi.org/10.1017/S0144686X05004538. 
Litwin, H., \& Shiovitz-Ezra, S. (2011). Social network type and subjective well-being in a national sample of older Americans. Gerontologist, 51, 379-388. https://doi.org/10.1093/geront/gnq094.

Melkas, T., \& Jylhä, M. (1996). Social network characteristics and social network types among Eldery People in Finland. In H. Litwin (Ed.), The social network of older people: A cross national analysis (pp. 99-116). Westport, CT: Praeger.

Molina, J. L. (2001). El análisis de redes sociales. Una introducción. Barcelona: Bellaterra.

Mugford, S., \& Kendig, H. (1986). Social relations: Networks and ties. In H. Kendig (Ed.), Ageing and families: A social networks perspective (pp. 38-59). Sydney: Allen and Unwin.

Neto, M. J., \& Corte-Real, J. (2013). A pessoa idosa institucionalizada: Depressão e suporte social. 26 Reunião do GEECD. http://www.spgg.com.pt/UserFiles/file/A\%20pessoa\%20idosa\%20institucional izada.pdf. Accessed 20 Sept 2018.

Pardo, E. N., Moral, J. C. M., \& Miguel, J. M. T. (2008). Análisis de las redes sociales en la vejez en función de la edad y el género. Revista Multidisciplinar de Gerontología, 18(1), 19-25.

Park, N. S., Jang, Y., Lee, B. S., Ko, J. E., Haley, W. E., \& Chiriboga, D. A. (2015). An empirical typology of social networks and its association with physical and mental health: A study with older Korean immigrants. The Journals of Gerontology Series B: Psychological Sciences and Social Sciences, 70(1), 67-76. https://doi.org/10.1093/geronb/gbt065.

Park, S., Smith, J., \& Dunkle, R. E. (2014). Social network types and well-being among South Korean older adults. Aging \& Mental Health, 18(1), 72-80. https://doi.org/10.1080/13607863.2013.801064.

Peters, G. R., \& Kaiser, M. A. (1985). The role of friends amd neighbors in providing social support. In W. J. Sauer \& R. T. Coward (Eds.), Social support networks and the care of the elderly. New York: Springer.

Phillipson, C., Bernard, M., Phillips, J., \& Ogg, J. (2001). The family and community life of older people. Social networks and social support in three urban areas. London: Routledge.

Portugal, S. (2011). Dádiva, família e redes sociais. In S. Portugal \& P. H. Martins (Eds.), Cidadania, políticas públicas e redes sociais (pp. 39-53). Coimbra: Coimbra University Press.

Portugal, S. (2014). Famílias e redes sociais. Ligações fortes na produção de bem-estar. Coimbra: Almedina.

Rodrigues, M. J. P. (2000). “Já não tenho família...”. Actas do IV Congresso Português de Sociologia Sociedade Portuguesa: Passados Recentes, Futuros Próximos. Coimbra: APS.

Shea, L., Thompson, L., \& Blieszner, R. (1988). Resources in older adults' old and new friendships. Journal of Social and Personal Relationships, 5(1), 83-96. https://doi.org/10.1177/0265407588051005.

Silva, P., \& Matos, A. D. (2012). Velhice, institucionalização e redes sociais. Atas do VII Congresso Português de Sociologia. Porto: APS.

Sluzki, C. E. (1996). La red social: Frontera de la practica sistemica. Barcelona: Gedisa Editorial.

Sluzki, C. E. (2000). Social network and the elderly: Conceptual and clinical issues, and a family consultation. Family Process, 39(3), 271-284. https://doi.org/10.1111/j.1545-5300.2000.39302.x.

Souza, L. K., \& Hutz, C. S. (2008). Relacionamentos pessoais e sociais: amizade em adultos. Psicologia em Estudo, 13(2), 257-265. https://doi.org/10.1590/S1413-73722008000200008.

Stone, L., \& Rosenthal, C. (1996). Profiles of the social networks of Canada's elderly: An analysis of 1990 General Social Survey Data. In H. Litwin (Ed.), The social networks of older people: A cross-national analysis (pp. 77-97). Westport: Praeger Publishers.

Thiyagarajan, J. A., Prince, M., \& Webber, M. (2014). Social support network typologies and health outcomes of older people in low and middle income countries: A 10/66 Dementia Research Group population-based study. International Review of Psychiatry, 26(4), 476-485. https://doi.org/10.3109/09540 261.2014.925850.

Tracy, E. M., Catalano, R. E., Whittaker, J. K., \& Fine, D. (1990). Reliability of social network data. Social Work Research \& Abstracts, 26(2), 33-35. https://doi.org/10.1093/swra/26.2.33.

Van der Poel, M. G. M. (1993). Delineating personal support networks. Social Networks, 15, 49-70. https:// doi.org/10.1016/0378-8733(93)90021-C.

Vasconcelos, P. (2005). Redes sociais de apoio. In K. Wall (Ed.), Famílias em Portugal - Percursos, interacções, redes sociais (pp. 599-631). Lisboa: Imprensa de Ciências Sociais.

Vassilev, I., Rogers, A., Kennedy, A., Wensing, M., Koetsenruijter, J., Orlando, R., et al. (2016). Social network type and long-term condition management support: A cross-sectional study in six European countries. PLOS ONE, 11(8), e0161027. https://doi.org/10.1371/journal.pone.0161027.

Vicente, H. T., \& Sousa, L. (2012). Redes sociais pessoais das gerações mais velhas: Famílias com quatro gerações vivas. Revista Temática Kairós Gerontologia, 15(2), 75-98.

Wellman, B. (1979). The community question: The intimate networks of East Yorkers. American Journal of Sociology, 84(5), 1201-1231. https://doi.org/10.1086/226906. 
Wellman, B. (1996). Are personal communities local? A Dumptarian reconsideration. Social Networks, 18(4), 347-354. https://doi.org/10.1016/0378-8733(95)00282-0.

Wenger, G. C. (1989). Support networks in old age: Constructing a typology. In M. Jefferys (Ed.), Growing old in the twentieth century (pp. 169-185). London: Routledge.

Wenger, G. C. (1991). A network typology: From theory to practise. Journal of Aging Studies, 5(2), 147162. https://doi.org/10.1016/0890-4065(91)90003-B.

Wenger, G. C. (1997). Social networks and the prediction of elderly people at risk. Aging \& Mental Health, 1(4), 311-320. https://doi.org/10.1080/13607869757001.

Wenger, G. C., Davies, R., Shahtahmasebi, S., \& Scott, A. (1996). Social isolation and loneliness in old age: Review and model refinement. Ageing \& Society, 16(3), 333-358. https://doi.org/10.1017/S0144 686 X00003457.

Willmott, P. (1987). Friendship networks \& social support. London: PSI Publications.

Wolff, F.-C. (2013). Well-being of elderly people living in nursing homes: The benefits of making friends. KYKLOS, 66(1), 153-171. https://doi.org/10.1111/kykl.12015.

Zumalde, E. C. (1994). Apoyo social y ancianos en residencias. Zerbitzuan: Gizarte zerbitzuetarako aldizkaria. Revista de servicios sociales, $25,71-76$.

Publisher's Note Springer Nature remains neutral with regard to jurisdictional claims in published maps and institutional affiliations. 